\title{
Assessment of the Effectiveness of Self Instructional Module on Knowledge Regarding Hazard of Plastic Waste and Its Safe Disposal among People
}

\author{
Achita Sawarkar, Madhuri Shambharka, Jaya Khandar, \\ Prerna Sakharwade, Sonali Kolheka, Vaishali Tembhare \\ Smt. Radhikabai Meghe Memorial College of Nursing, Sawangi (Meghe), Wardha, Datta \\ Meghe Institute of Medical Sciences (Deemed to be University) Maharashtra, India. \\ Corresponding author email: achitasawarkar5@gmail.com
}

\section{ABSTRACT}

plastic are the integral part of the society and have a valid application. Plastics are composed of network of molecule bound together to form a micromolecules plastic waste management is the critical issue plastic found in the electrical and cooking appliance are the mixture of thermosetting plastic. plastic waste rules 2016 of a directives to gram panchayat on segregation collection transportation processing and disposal of plastic waste in their areas of jurisdiction. To assess the existing knowledge of self instructional module on Knowledge regarding hazards of plastic waste and its disposal among people. 2) To assess the effectiveness of self instructional module on Knowledge regarding hazards of plastic waste and its disposal among people. 3) To associate knowledge with the selected demographic variable. Research approachQuantitative research approach Pre experimental- one group pre test post test research design. Research Setting- The study will be conducted in Arvi naka, wardha. Sampling technique: Non Probability-convenient sampling technique. Sample size:100 Structured questionnaire were used to collect the data. The content validity of the tool was done by various experts from different fields. pre test, $15 \%$ of people in pre test had poor level knowledge score, 83\% had average and only $2 \%$ had good level of knowledge score. In post test $13 \%$ of people in post test had good level of knowledge score, and $87 \%$ had excellent level of knowledge score. After the detailed analysis, the study lead to the following conclusion that there was a lack of knowledge among people regarding hazards of plastic waste and its safe disposal.

KEY WORDS: KNOWLEDGE, SELF INSTRUCTIONAL MODULE, HAZARDS, PLASTIC WASTE, SAFE DISPOSAL.

\section{INTRODUCTION}

The word "plastic" comes from the Greek word "plastikos" meaning "to form". Plastics is any of a group of synthetic or natural organic materials that may be shaped when soft and then hardened, including many types of resins, resinoids, polymers, cellulose derivatives, casein materials, and proteins: used in place of other materials, as glass, wood, and metals, in construction and decoration, for making many articles, as coatings, and, drawn into filaments, for weaving. The material

Biosc Biotech Res Comm P-ISSN: 0974-6455 E-ISSN: 2321-4007
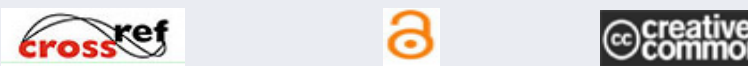

Identifiers and Pagination

Article Information

Year: 2021 Vol: 14 No (9) Special Issue

Pages: 305-309

Received: $17^{\text {th }}$ July 2021

This is an open access article under Creative

Commons License Attribn 4.0 Intl (CC-BY).

DOI: http://dx.doi.org/10.21786/bbrc/14.9.56 called Parkesine was an organic material derived from cellulose that once heated could be molded, and retained its shape when cooled. Celluloid is derived from cellulose and alcoholised camphor. He first tried using collodion a natural substance, after spilling a bottle of it and discovering that the material dried into a tough and flexible film. However, the material was not strong enough to be used as a billiard ball, until the addition of camphor, a derivative of the laurel tree. The new celluloid could be molded with heat and pressure into a durable shape. Almost all plastics are made from petroleum, except a few experimental resins derived from corn and other organic substances (Alabi et al., 2019).

Plastics are polymers, very long chain molecules that consist of subunits (monomers) linked together by chemical bonds. The monomers of petrochemical plastics are inorganic materials (such as styrene) and are not biodegradable. Plastic has many properties which has 
made it a raw material of choice for Manufactures of plastic Bags and packing materials. Cost of production, light weight, strength, easy process of manufacture. There is nothing wrong with plastic as a material. Man has simply not put the plastic to the right use/ or using it without taking proper care of other related norms of usage. It is very difficult to release how important plastics have become to our everyday lives. We always seem to have known these materials, and we tend to take it for granted that they occur every day and all around us, for example in our clothing, Plastic are the integral part of the society and have varied application plastics are composed of network of molecular monomers bound together to form micro molecule." Plastic waste management is the critical issue" plastic found in the electrical and cooking appliance are the mixture of thermo setting plastic Plastic waste rules 2016.

offer directives to gram panchayat on segregation, collection, transportation, processing and disposal of plastic waste in their areas of jurisdiction. A study of the environment on the cusp of the twenty-first century is an exciting end devour as we attempt to move from confrontation to co-operative problem-solving and place the study of the environment on a sound scientific basis. 4 At the dawn of creation there was a perfect balance between man and his environment. Due to human activities on earth the stable equilibrium between man and his environment was broken and hence the resultant environmental problems .As humans we are part of the environment and the way we interact with the environment influences the quality of our lives.

\section{MATERIAL AND METHODS}

A interventional study was conducted in Wardha city to assess the effectiveness of self instructional module on knowledge regarding hazard of plastic waste and its safe disposal among people. Duration of study was one year. Approval had been taken from Institutional Ethics Committee (under protocol number DMIMS (DU)/ IEC/2018-19/7619). The participants people of Wardha district. Total 100 people was participated in this study. Non Probability - convenient sampling technique was used to select sample. Modified structured questionnaire was used to assess knowledge regarding hazard of plastic waste and its safe disposal. Question was divided in two sections. Section one includes demographic variable such as age gender, education, occupation, Monthly Income, Section two includes knowledge based 20 multiple choice questions in that 10 questions on plastic waste related health hazards and 10 questions related to safe disposal of plastic waste One mark is given for right answer and zero mark is given for wrong answer. The data was collected from 22thjanuary 2019 to 7th February 2019.

The investigators visited to the different area of Wardha city and assess the knowledge by taking pre test regarding hazard of plastic waste and its safe disposal after that self instructional module was administered at the end of the pre-test. The post-test was carried out after 7 days, In advance obtained the necessary permission from the ward member of Wardha city 20 minutes were allotted to solve the questions. Study was conducted according to ethical guidelines given by central ethics committee on human research. The collected data was entered and analyzed in MS Excel. Descriptive statistics like frequencies and percentages were used for representing the analyzed data (Lebreton \& Andrady 2019).

\section{RESULTS AND DISCUSSION}

The table no 2 shows the frequency and percentage wise distribution of people according to pre- test level of knowledge regarding hazard of plastic waste and its safe disposal among people. The levels of knowledge were seen into 4 categories, poor, average, good and excellent. $15 \%$ of people in pre test had poor level of knowledge score, 83\% had average and only 2\% had good level of knowledge score. Mean knowledge score of the people in pre test was $7.20 \pm 1.84$.

Table 1. Percentage wise distribution of people according to their demographic characteristics $\mathrm{N}=100$

\begin{tabular}{|c|c|c|}
\hline Demographic Variables & No of people & Percentage \\
\hline & Age in years & \\
\hline $21-30$ yrs & 21 & 21 \\
\hline $31-40$ yrs & 27 & 27 \\
\hline $41-50$ yrs & 42 & 42 \\
\hline \multirow{2}{*}{$\geq 51$ yrs } & 10 & 10 \\
\hline & Gender & \\
\hline Male & 39 & 39 \\
\hline \multirow[t]{2}{*}{ Female } & 61 & 61 \\
\hline & Residence & \\
\hline Rural & 32 & 32 \\
\hline \multirow[t]{2}{*}{ Urban } & 68 & 68 \\
\hline & Educational Status & \\
\hline Primary & 10 & 10 \\
\hline Secondary & 59 & 59 \\
\hline Higher Secondary & 23 & 23 \\
\hline \multirow[t]{2}{*}{ Graduate and above } & 8 & 8 \\
\hline & Occupation & \\
\hline Service & 8 & 8 \\
\hline Private & 36 & 36 \\
\hline Student & 11 & 11 \\
\hline \multirow[t]{2}{*}{ Housewife } & 45 & 45 \\
\hline & Monthly Income(Rs) & \\
\hline $10000-15000 \mathrm{Rs}$ & 12 & 12 \\
\hline $16000-20000 \mathrm{Rs}$ & 34 & 34 \\
\hline $21000-30000$ Rs & 29 & 29 \\
\hline$>30000$ Rs & 25 & 25 \\
\hline
\end{tabular}

The table no 3 shows the frequency and percentage wise distribution of people according to post test level of knowledge regarding hazard of plastic waste and its safe disposal among people. The levels of knowledge were seen into 4 categories, poor, average, good and 
excellent. $13 \%$ of people in post test had good level of knowledge score, and 87\% had excellent level of knowledge score. Mean knowledge score of the people in post test was $17.05 \pm 1.46$ (Manuel et al., 2015).

\begin{tabular}{|c|c|c|c|c|}
\hline \multirow{2}{*}{$\begin{array}{l}\text { Level of knowledge } \\
\text { score }\end{array}$} & \multirow[t]{2}{*}{ Score Range } & \multirow[t]{2}{*}{ Percentage score } & \multicolumn{2}{|c|}{ Level of Pre Test Knowledge Score } \\
\hline & & & No of people & Percentage \\
\hline Poor & $1-5$ & $0-25 \%$ & 15 & 15 \\
\hline Average & $6-10$ & $26-50 \%$ & 83 & 83 \\
\hline Good & $11-15$ & $51-75 \%$ & 2 & 2 \\
\hline \multirow[t]{4}{*}{ Excellent } & $16-20$ & $76-100 \%$ & 0 & 0 \\
\hline & \multicolumn{2}{|l|}{ Mean \pm SD } & \multicolumn{2}{|c|}{$7.20 \pm 1.84$} \\
\hline & \multicolumn{2}{|l|}{ Mean \% } & \multicolumn{2}{|c|}{$36 \pm 9.23$} \\
\hline & \multicolumn{2}{|l|}{ Range } & \multicolumn{2}{|c|}{3 to 11} \\
\hline
\end{tabular}

Table 3. Distribution of people with regards to post- test knowledge regarding hazard of plastic waste and its safe disposal $n=100$

\begin{tabular}{|l|c|c|c|c|}
\hline \multirow{2}{*}{$\begin{array}{l}\text { Level of knowledge } \\
\text { score }\end{array}$} & \multirow{2}{*}{ Score Range } & \multirow{2}{*}{ Percentage score } & Level of Post Test Knowledge Score \\
\cline { 3 - 5 } & & & No of people & Percentage \\
\hline Poor & $1-5$ & $0-25 \%$ & 0 & 0 \\
\hline Average & $6-10$ & $26-50 \%$ & 0 & 0 \\
\hline Good & $11-15$ & $51-75 \%$ & 13 & 13 \\
\hline Excellent & $16-20$ & $76-100 \%$ & 87 & 87 \\
\hline \multicolumn{4}{|c|}{} \\
\hline \\
Mean \pm SD \\
Mean $\%$ \\
Range \\
\hline
\end{tabular}

\section{DISCUSSION}

The present interventional study focuses on. assess the effectiveness of self instructional module on knowledge regarding hazard of plastic waste and its safe disposal among people. The population of the study consists of people of Wardha city . The sample size included 100people. Modified structured questionnaire used to assess the baseline information and knowledge regarding hazard of plastic waste and its safe disposal.

The study result are discussed under the following headlines -

- Environmental hazards and health issues due to plastic.

- Disposal of plastic waste and its safe disposal

- Effectiveness of self instructional module on knowledge regarding disposal of plastic wastes.

A similar study the findings of the study were discussed with reference. A detailed review of literature indicated that most of the studies indicating that after self instructional module improve knowledge regarding hazards of plastic waste among people. The overall mean pre- test and post -test knowledge scores of people which reveals that mean post knowledge score was higher i.e. 17.05 with $\mathrm{SD}$ of \pm 1.46 when compared with mean pre- test knowledge score which was 7.20 with SD of \pm 1.84 . The statistical Student's paired t test implies that the difference in the pre- test and post- test knowledge among people was found to be 43.53 which is statistically significant at $0.05 \%$ level of significance. The findings of the preset study reveal that many of the peoples do not have adequate knowledge regarding hazards of plastic waste and its safe disposal. thus the above studies support the findings of the present study.

A similar study is conducted by Bangalore in rural community area on Hazards of plastic waste and its safe disposal a total 100 rural community people in the all age group where included in the study. The investigator found that the people were co-operative in the study. The investigator collected the demographic data from the people A detailed review of literature indicated that most of the studies indicating that after self instructional module improve knowledge regarding hazards of plastics and its safe disposal among people. Self instructional module is effective method of transforming knowledge. This study was the modest effort to increase the knowledge regarding hazards of plastics and its safe disposal among people (Moharir \&t Kumar 2019). 
A similar study conducted survey to assess the quantity and composition of household solid waste as well as household habits and behaviors of plastic waste discharge. conducted a survey to assess the quantity and composition of household solid waste as well as household. The data was collected from 130 households using interview technique. The average household solid waste generation rate was $281.27 \mathrm{~g} / \mathrm{cap} /$ day. The compostable and recyclable shared $80.74 \%$ and $11 \%$ respectively. Plastic waste discharge indicating Inappropriate practices and unhygienic disposal methods. The study indicates the need to adopt right disposal and recycling techniques to avoid hazards. thus, above study support to present study (Panda et al., 2010).

A similar study conducted at ullal to assess the knowledge of nursing personnel on plastic waste management by using a structured knowledge questionnaire. The study revealed that among 100subjects, $64 \%$ had poor knowledge, 36\% had average knowledge and none of the subjects had good or excellent knowledge on plastic waste. Based on these, the students gave health teaching using A.V. aids and post test revealed 18\% of subjects with excellent knowledge and 34\% with good knowledge. The investigators then concluded saying that continuing nursing education on plastic waste management was effective in improving the knowledge of subjects on waste management. thus, above study support to present study (Puncochár et al., 2012).

Conducted a descriptive survey at 62 Zehrs shopping centre at Ontario to assess knowledge of people of all age groups regarding reuse of plastic bags. It is evident that majority of people's knowledge was in line with the desired behavior of using reusable bags; they believe that the behavior of using plastic bags is harmful to the environment and unsustainable. Hence, efforts should be made to decrease or eliminate this behavior. The investigator further said that the reuse of the bag has not become a permanent habit. Hence, the need to build up strategies to encourage the public for using reusable bags. thus, above study support to present study. The overall mean pre- test and post -test knowledge scores of people which reveals that mean post knowledge score was higher i.e. 17.05 with SD of \pm 1.46 when compared with mean pre- test knowledge score which was 7.20 with SD of \pm 1.84 (Rochman et al., 2013).

A similar study the statistical Student's paired t test implies that the difference in the pre-

test and post- test knowledge among people was found to be 43.53 which is statistically

significant at 0.05\% level of significance.

The findings of the present study reveal that many of the peoples do not have adequate knowledge regarding hazards of plastic waste and its safe disposal

\section{Nursing administration}

- Nurse administrators can utilize the educational material while organizing classes and workshops related to the topic.

- Findings of the study can be used by the Nursing Administrator in creating policies and plans for educating community member regarding dispose of plastic waste.

- The study will help the nursing administrator to plan and organize to give continuing education for nurses regarding Hazards of plastic waste and its safe disposal.

\section{Nursing education}

- This study will help the nursing students in improving knowledge regarding Hazards of plastic waste and its safe disposal.

- Findings of this study will help the nursing student to understand about the necessity of hazards of plastic waste and its safe disposal.

- Teachers can utilize the tools and study findings to teach students about research methodology in the class room (Singh \& Ruj 2015).

\section{Nursing research}

- The study provides a baseline data for conducting other research studies.

- The study will be a motivation for the budding researchers to conduct similar studies in large scale.

- Similar studies can be conducted in various other settings and in other groups after making necessary modifications in the tools.

- This study can be utilized as a reference material for future researchers (Sen \&t Mishra 2010).

- The tools us

\section{Nursing practice}

- The staff and student nurses can use the knowledge towards hazards of plastic waste and its safe disposal.

- The Self instructional module on hazards of plastic waste and its safe disposal is a resource material to build up a general awareness campaign and spread the message of hazards and safe disposal of plastic in community (Shahnawaz et al., 2019).

Recommendations: On the basis of findings of the study it is recommended that the following studies can be conducted (Verma et al., 2016).

- The study can be repeated by taking more sample of community people.

- The study can be repeated by assessing the effectiveness of self instructional module.

- A similar study should be done by using control group.

- A comprehensive study to assess the knowledge urban and rural community people should be done (Singh \&t Sharma 2016).

\section{Nursing Implications}




\section{CONCLUSION}

After the detailed analysis, the study lead to the following conclusion that there was a lack of knowledge among people regarding hazards of plastic waste and its safe disposal.

\section{REFERENCES}

Alabi, O.A., Ologbonjaye, K.I., Awosolu, O. and Alalade, 0.E., (2019). Public and environmental health effects of plastic wastes disposal: a review. J Toxicol Risk Assess, 5(021), pp.1-13.

Lebreton, L. and Andrady, A., (2019). Future scenarios of global plastic waste generation and disposal. Palgrave Communications, 5(1), pp.1-11.

Manuel, J., Varghese, J., Jose, J., Thomas, J.K., Joseph, J. and Shettigar, D., (2015). An Educational Intervention Programme on Hazards of Plastic Waste and Its Disposal among Adults: A Rural Community Based Study. Journal of Health and Allied Sciences NU, 5(02), pp.016-018 Moharir, R.V. and Kumar, S., (2019). Challenges associated with plastic waste disposal and allied microbial routes for its effective degradation: a comprehensive review. Journal of Cleaner Production, 208, pp.65-76.

Panda, A.K., Singh, R.K. and Mishra, D.K., (2010). Thermolysis of waste plastics to liquid fuel: A suitable method for plastic waste management and manufacture of value added products-A world prospective. Renewable and Sustainable Energy Reviews, 14(1), pp.233-248.

Puncochár, M., Ruj, B. and Chatterj, P.K., (2012). Development of process for disposal of plastic waste using plasma pyrolysis technology and option for energy recovery. Procedia Engineering, 42, pp.420430.

Rochman, C.M., Browne, M.A., Halpern, B.S., Hentschel, B.T., Hoh, E., Karapanagioti, H.K., Rios-Mendoza, L.M., Takada, H., Teh, S. and Thompson, R.C., (2013). Classify plastic waste as hazardous. Nature, 494(7436), pp.169171..

Singh, R.K. and Ruj, B., (2015). Plasticwaste management and disposal techniques-Indian scenario. International Journal of Plastics Technology, 19(2), pp.211-226.

SHAHNAWAZ, Mohd; SANGALE, Manisha K.; ADE, Avinash B. Plastic waste disposal and reuse of plastic waste. In: Bioremediation Technology for Plastic Waste. Springer, Singapore, 2019. p. 21-30.

Singh, P. and Sharma, V.P., (2016). Integrated plastic waste management: environmental and improved health approaches. Procedia Environmental Sciences, 35, pp.692-700.

Sen, T. and Mishra, U., (2010). Usage of Industrial Waste Products in VillageRoad Construction. International Journal of Environmental Science and Development, $1(2)$, p.122.

Verma, R., Vinoda, K.S., Papireddy, M. and Gowda, A.N.S., (2016). Toxic pollutants from plastic waste-a review. Procedia Environmental Sciences, 35, pp.701708. 